\title{
Cell size dynamics and viability of cells exposed to hypotonic treatment and electroporation for electrofusion optimization
}

\author{
Marko Ušaj, Katja Trontelj, Rosana Hudej, Maša Kandušer, Damijan Miklavčič
}

University of Ljubljana, Faculty of Electrical Engineering, Ljubljana, Slovenia

Background. Various electrofusion parameters have to be adjusted to obtain the optimal electrofusion ef-
ficiency. Based on published data, good electrofusion conditions can be achieved with the hypotonic treat-
ment. However, the duration of the hypotonic treatment before electroporation and buffer hypoosmolarity
have to be adjusted in order to cause cell swelling, to avoid regulatory volume decrease and to preserve
cell viability. The aims of our study were to determine cell size dynamics and viability of four different
cell lines in hypotonic buffer and to study the influence of the electroporation on the selected cell line in
hypotonic buffer. Materials and methods. Cell size dynamics of different cell lines exposed to hypotonic buffer and electroporation were analyzed by time-resolved cell size measurements. The viability of hypotonically treated or/and electroporated cells was determined $24 \mathrm{~h}$ after the experiment by a modified crystal violet (CV) viability assay.

Results. In our experimental conditions the hypotonic treatment at $100 \mathrm{mOsm}$ was efficient for CHO, V79 and B16-F1 cell lines. The optimal duration of the treatment was between two and five minutes. On the other hand the same hypotonic treatment did not cause cell swelling of NS1 cells. Cell swelling was also observed after electroporation of B16-F1 in isotonic buffer and it was amplified when hypotonic buffer was used. In addition, the regulatory volume decrease was successfully inhibited with electroporation.

Conclusions. Cell size dynamics in hypotonic conditions should be studied for each cell line since they differ in their sensitivity to the hypotonic treatment. The inhibition of cell regulatory volume decrease by electroporation may be beneficial in achieving higher electrofusion efficiency. The hypotonic treatment in itself did not significantly affect the cell viability; however, electric field parameters for electroporation should be carefully selected taking into account the hypotonically induced volume increase of cells.

Key words: hypotonic treatment; cell swelling; regulatory volume decrease; cell size measurements; viability; electrofusion; electroporation

Received 10 March 2009

Accepted 25 March 2009

Correspondence to: Prof. Dr. Damijan Miklavčič, University of Ljubljana, Faculty of Electrical Engineering, Tržaška 25, SI-1000 Ljubljana, Slovenia; Phone: +386 14768 456; Fax: +386 14264 658; E-mail: damijan.miklavcic@fe.uni-lj.si

\section{Introduction}

Electrofusion of two different types of cells generates a third polynuclear type, which displays hybrid characteristics of the two parental cells. Different methods 
are used to achieve cell fusion; however, electrofusion is gaining on its importance because it is easy to use, potentially highly efficient, reproducible and controllable. ${ }^{1-3}$ Electrofusion has great potential for clinical applications, with respect to viral and chemical methods, because it is a safe method that does not introduce any foreign substances into the body.

Cell fusion is a two-condition process: (I) cell membrane has to be brought into fusogenic state and (II) a close physical contact of two fusogenic membranes has to be established. The fusogenic state of cell membrane is achieved by electroporation. ${ }^{4-6}$ Electroporation is a method, widely used in medicine $\mathrm{e}^{7-12}$, where a dramatic increase in membrane permeability is caused by cell exposure to short and intense electric pulses. ${ }^{13-15}$ With the appropriate selection of electrical parameters and media, taking into account biological characteristics of the treated cells, the reversible electroporation can be obtained. The reversible electroporation does not affect cell viability, because cell membranes reseal after the treatment. ${ }^{16-21}$

As mentioned before, the second condition required for cell fusion is a close physical contact between cells which has to be established during the fusogenic state of the membrane. A physical contact between cells can be achieved by the application of alternating electric filed which causes dielectrophoretic forces that result in cell migration and pearl chain formation. ${ }^{4,22}$

Even though electrofusion of biological cells is potentially a useful method, achieving the sufficient efficiency still requires extensive trial-and-error studies. ${ }^{23-26}$ One of the earliest approaches to improve electrofusion efficiency was the use of hypotonic electrofusion buffer that resulted in the considerable fusion efficiency increase. ${ }^{27-34}$ To ensure the improvement of fusion efficiency in hypotonic buffer the duration and the osmolarity of the hypotonic treatment has to be selected and used properly. Rapid cell swelling in the hypotonic environment due to influx of water namely triggers regulatory the volume decrease. If it is triggered before the induction of cell fusion, it can inhibit the positive effect of the hypotonic treatment on electrofusion by reducing cell size, restoring microvilli and excessive leaking of cytosolic electrolytes. ${ }^{33,35}$ The prolonged treatment thus leads to poor fusion efficiency and also decreases the cell viability. ${ }^{30,32-34}$

The aim of our study was first to determine cell size dynamics and the viability of four different cell lines in hypotonic buffer. The volume regulation of different cell lines exposed to strongly hypotonic buffers was analyzed by means of time-resolved cell size measurements. The second aim of our study was to determine the influence of the electroporation on the selected cell line in hypotonic buffer. B16-F1 cell line was selected because electroporation parameters and swelling induced by electroporation in isotonic buffer were previously well described for this cell line. ${ }^{21,36}$

\section{Materials and methods}

\section{Chemicals, cell culture media}

Eagle's minimal essential medium (EMEM), Ham's Nutrient Mixtures (F-12 HAM), Dulbecco's Modified Eagle's Medium (DMEM), trypsin, fetal bovine serum (FBS), L-glutamine, sucrose, phosphate $\left(\mathrm{K}_{2} \mathrm{HPO}_{4} /\right.$ $\left.\mathrm{KH}_{2} \mathrm{PO}_{4}\right), \mathrm{MgCl}_{2}$, crystal violet, trypsin and EDTA were purchased from Sigma (Sigma-Aldrich Chemie GmbH, Germany). Antibiotics (crystacillin and gentamicin) were purchased from Lek (Ljubljana, Slovenia).

\section{Cells}

All cell lines were cultured in an incubator (Kambič, Slovenia) in the humidified 
Table 1. Chemical composition, conductivity and osmolarity of isotonic and hypotonic buffers used in our experiments.

\begin{tabular}{lll}
\hline Ingredients & Isotonic & Hypotonic \\
\hline Phosphate buffer & $10 \mathrm{mM}$ & $10 \mathrm{mM}$ \\
$\mathrm{MgCl}_{2}$ & $1 \mathrm{mM}$ & $1 \mathrm{mM}$ \\
Sucrose & $250 \mathrm{mM}$ & $75 \mathrm{mM}$ \\
$\mathrm{pH}$ & 7,2 & 7,2 \\
Conductivity & $1.62 \mathrm{mS} / \mathrm{cm}$ & $1.62 \mathrm{mS} / \mathrm{cm}$ \\
Osmolarity & $260 \mathrm{mOsm}$ & $93 \mathrm{mOsm}$ \\
\hline
\end{tabular}

atmosphere at $37^{\circ} \mathrm{C}$ and $5 \% \mathrm{CO}_{2}$ in the following culture media: murine melanoma (B16-F1) and Chinese hamster lung fibroblast (V79) in EMEM supplemented with $10 \%$ fetal bovine serum (FBS), antibiotics (gentamicin, crystacillin) and L-glutamine; Chinese hamster ovary cells (CHO) in F-12 HAM supplemented with $10 \%$ FBS, antibiotics and L-glutamine; mouse myeloma NS1 in DMEM supplemented with 13\% FBS, antibiotics and L-glutamine. Cell lines were grown in $25 \mathrm{~cm}^{2}$ culture flask (TPP, Switzerland) until they reached $80-90 \%$ confluence. Adherent cells were exposed to $0.25 \%$ trypsin/EDTA solution for 1 minute. Trypsin solution was then removed and $5 \mathrm{ml}$ of culture media was added. Cells were gently rinsed from the bottom with a plastic pipette and the homogenous cell suspension was prepared. For cell size dynamics and viability measurements in hypotonic buffer $5 \times 10^{5}$ cells were placed on Petri dish (see Cell size measurement and analysis section). For viability tests after the electroporation, cell suspension was centrifuged $\left(290 \times \mathrm{g}, 5 \mathrm{~min}, 4^{\circ} \mathrm{C}\right)$ and then resuspended in the electroporation buffer (details explained in Cell viability section).

\section{Isotonic and hypotonic buffers}

Iso- and hypo-tonic buffers (phosphate buffer saline - PBS) of osmolarities 260 and $93 \mathrm{mOsm}(\mathrm{mOsmol} / \mathrm{kg}$ ) and conductivity $1.62 \mathrm{mS} / \mathrm{cm}$ were used (Table 1). The os- molarity of solutions was determined with Knauer vapor pressure osmometer K-7000 (Knauer, Wissenschaftliche Gerätebau, Germany). Buffers pH was 7.2.

\section{Cell size measurement and analysis}

Cell volume changes were measured by protocol which allowed a rapid exchange of media. For that purpose we used $9.2 \mathrm{~cm}^{2}$ tissue culture Petri dishes (TPP, Switzerland). Before the microscopic measurement, cells in suspension were counted by haemocytometer and $5 \times 10^{5}$ cells were placed on Petri dish. Cells were incubated at $37^{\circ} \mathrm{C}$ for 20-40 $\min$ (except for NS1, which were incubated overnight) in culture medium allowing cells to slightly adhere but still preserving a round shape. Culture medium was removed and cells were washed with $1 \mathrm{ml}$ isotonic buffer leaving $300 \mu \mathrm{l}$ to avoid drying of the sample during the acquisition of the first image (represents time $t$ $=0 \mathrm{~min}$ ). Cells were observed under the Axiovert 200 microscope (Zeiss, Germany) with $40 \times$ objective in transmitted light. Phase contrast images were acquired with cooled CCD video camera VisiCam 1280 (Visitron, Germany) and PC software MetaMorph 7.0 (Molecular Devices, USA). After the first image was acquired $3.3 \mathrm{ml}$ hypotonic buffer was added to the cells (in the control samples isotonic buffer was used). The resulting osmolarity of hypotonic buffer was calculated to $100 \mathrm{mOsm}$. Images of cells were then taken at various time intervals up to $30 \mathrm{~min}$ after the buffer exchange (every $15 \mathrm{~s}$ until $2 \mathrm{~min}$ and in minute steps after that). One to three sequences were recorded of each repetition of every experiment (cell line).

Cell diameters of 5-10 cells per image were determined at each time interval (37 images in every sequence). Cell size dynamic was defined as the relative change of cell diameter $=d / d_{0}$, where $d$ is an actual 
cell diameter and $d_{0}$ is an initial one (at $t=0$ min). The mean values ( \pm STD) for a given experiment (cell line) were calculated from at least three independent repetitions of the experiments and plotted against time. The script was written in Matlab (Matlab 2008a, Math Works, USA) for all calculations to enhance calculation speed and graph performance. Observed differences between cell lines were statistically tested using ANOVA test or One-Sample T test (SPSS Statistics).

\section{Electroporation}

In the second part of our study, where we studied the effect of electroporation on B16-F1 cells swelling in isotonic and hypotonic buffers, the protocol was slightly altered from the one described previously. One minute after the buffer exchange from isotonic to hypotonic (or to isotonic again for control) electric pulses were delivered using two parallel electrodes ( $\mathrm{Pl} / \mathrm{Ir}=90 / 10)$ and an electric pulse generator Cliniporator (IGEA, Italy). We used electrical parameters optimal for transient permeabilization of B16-F1 cells in the isotonic buffer (1000 $\mathrm{V} / \mathrm{cm}, 8 \times 100 \mu \mathrm{s}, 1 \mathrm{~Hz}$ ) described in our previous studies. ${ }^{21,36}$ Cell sizes were measured and analyzed as described previously.

\section{Cell viability}

The viability of hypotonically treated cells as well as electroporated cells was analyzed $24 \mathrm{~h}$ after experiments by means of a modified crystal violet $(\mathrm{CV})$ viability assay. ${ }^{37}$ From prepared cell suspension $10^{5}$ cells per well were plated to 24 - well microplates (TPP, Switzerland) and incubated at $37^{\circ} \mathrm{C}$ for 20-40 $\mathrm{min}$ in culture medium to settle and to slightly adhere. After the incubation culture medium was carefully removed and cells were washed with $1 \mathrm{ml}$ isotonic buffer. One $\mathrm{ml}$ of hypotonic buffer was added to the cells in each well. In control $1 \mathrm{ml}$ of culture medium was added. After a hypotonic treatment (30 min at room temperature) all media (buffer and culture medium in control) was carefully removed and $1 \mathrm{ml}$ of fresh culture medium was added. Cells were then cultured in the incubator for $24 \mathrm{~h}$. In described protocol washing, removing and adding medium were the same for treated cells as well as for the control ones.

After $24 \mathrm{~h}$ culture medium was removed and cells were washed with the isotonic buffer ( $1 \mathrm{ml}$ per well) $0.1 \% \mathrm{CV}$ solution prepared in the isotonic buffer was then added (200 $\mu \mathrm{l}$ per well). After $30 \mathrm{~min}$ of incubation at room temperature dye was carefully removed and cells were washed three times with the isotonic buffer per well $(200 \mu \mathrm{l}$, $500 \mu \mathrm{l}, 1000 \mu \mathrm{l})$. After the washing procedure cells were lysed by $10 \%$ acetic acid ( $1 \mathrm{ml}$ per well). The same lysis procedure was also applied to wells without cells and their absorption values were used as the background. The absorption of lysate was measured with a microplate reader Infinite M200 (Tecan, Switzerland) at $595 \mathrm{~nm}$ wavelength controlled with PC software i-Control (Tecan, Switzerland) at maximum $1 \mathrm{~h}$ after the dying procedure. The viability of treated cells was defined as

$$
V C=\frac{\left(A_{T C}-A_{B g}\right)}{\left(A_{C C}-A_{B g}\right)} \times 100,
$$

where

$\mathrm{V}_{\mathrm{c}} \ldots$ viability [\%]

$\mathrm{A}_{\mathrm{TC}} \ldots$ absorption value of treated cells

$A_{C C} \ldots$ absorption value of control cells (100\% viability)

$\mathrm{A}_{\mathrm{Bg}} \ldots$ absorption value of background

The mean $V_{c}$ values $( \pm$ STD) for a given cell line were calculated from three independent experiments.

In the second part of our study, where we studied the effect of electroporation on 


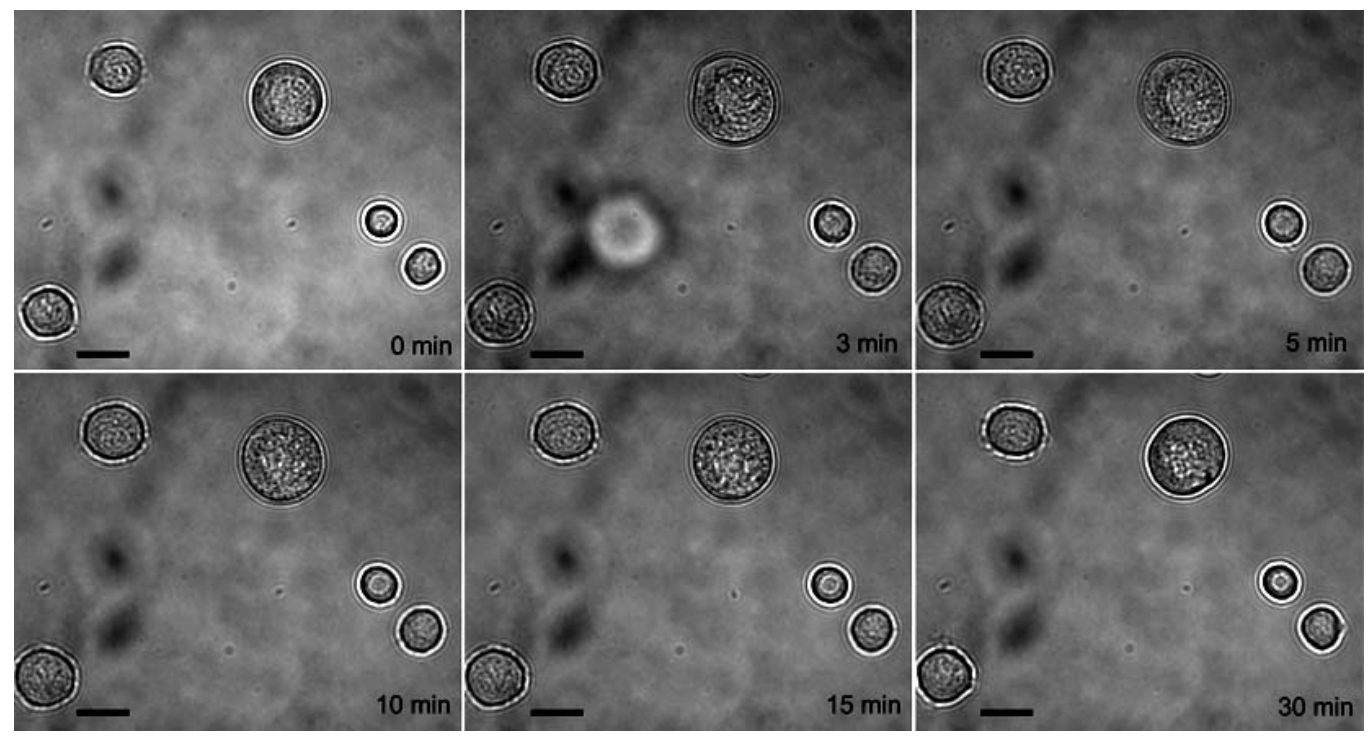

Figure 1. Swelling and regulatory volume decrease of B16-F1 cells in $100 \mathrm{mOsm}$ buffer containing sucrose as the major osmolyte. The images show the same cells before $(0 \mathrm{~min})$ and during the hypotonic treatment at the indicated time intervals. After the rapid change of isotonic to hypotonic buffer at zero time, the cells swelled within $5 \mathrm{~min}$ and then shrank gradually within the observed time $(5-30 \mathrm{~min})$. Scale bar corresponds to $30 \mu \mathrm{m}$.

B16-F1 cells swelling, the viability protocol was slightly altered from the one described above. In order to expose cells to an electric field, electroporation cuvettes with $4 \mathrm{~mm}$ gap (Eppendorf, Germany) were used. The cell suspension prepared in cell culture media was counted and aliquots of $5 \times 10^{5}$ cells were prepared and centrifuged $(290 \times \mathrm{g}, 5$ $\min , 4^{\circ} \mathrm{C}$ ). Supernatant was carefully removed and cells were resuspended in $1 \mathrm{ml}$ of hypotonic buffer (or culture media for control). One minute after the hypotonic buffer was added, $800 \mu \mathrm{l}$ of cell suspension was electroporated. In the control treatment no pulses were delivered. After the electroporation cells were kept at room temperature for $10 \mathrm{~min}$ and on $37^{\circ} \mathrm{C}$ for another $10 \mathrm{~min}$ to allow membrane resealing. From each cuvette $600 \mu \mathrm{l}$ of cell suspension was plated in three microplate wells ( 24 - well microplates, TPP, Switzerland). Finally $1 \mathrm{ml}$ of culture medium was added to each well and cells were incubated for $24 \mathrm{~h}$. The cell viability was then determined with the crystal violet assay as described above. Differences between electroporated and non-electroporated (control) cells were tested by the Paired samples T test (SPSS Statistics).

\section{Results}

\section{Cell size dynamics due to exposure to hypotonic buffer}

We monitored cell size (diameter) changes in B16-F1, CHO, V79 and NS1 cells after the rapid change of isotonic to hypotonic buffer. From the microphotographs such as shown in Figure 1, the diameters of individual cells were evaluated and normalized to the original isotonic diameter $\left(v=d / d_{0}\right.$, Figure 2). The hypotonic treatment caused $\mathrm{CHO}, \mathrm{V} 79, \mathrm{~B} 16-\mathrm{F} 1$ cells to swell rapidly within first minutes from their initial isotonic diameters $\left(\mathrm{d}_{0}\right)$ to their maximum diameters $\left(\mathrm{d}_{\max }\right)$ due to a fast water uptake driven by the imposed osmotic gradient. 


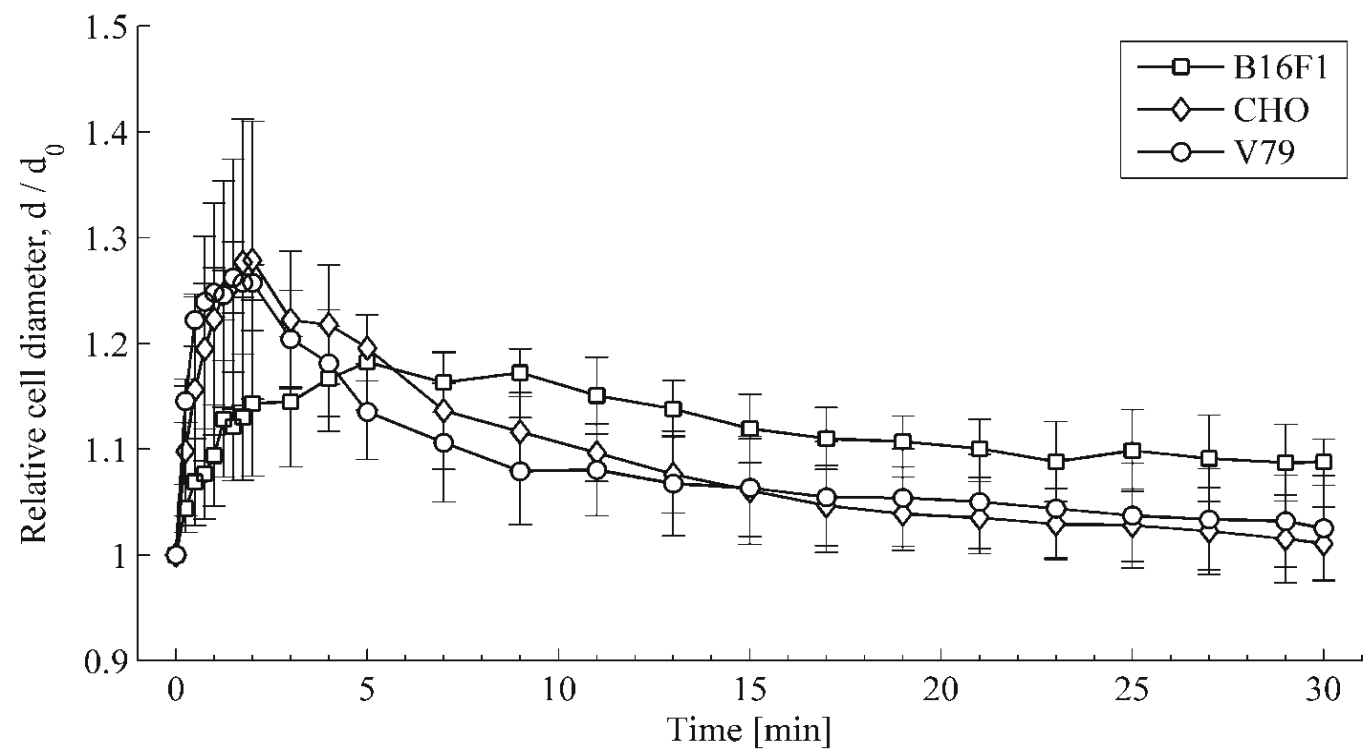

Figure 2. Cell dynamics $\left(\mathrm{d} / \mathrm{d}_{0}\right)$ in hypotonic buffer for three different cell lines. Cell dynamics was obtained by directly measuring the size of the cells. Each data point represents the mean \pm STD of at least three repetitions. One-Sample $\mathrm{T}$ test showed that after $30 \mathrm{~min}$ in the hypotonic buffer cell size of V79 and CHO did not differ significantly from their initial isotonic size $(P>0,1)$ while B16-F1 cells remained significantly enlarged $d_{\text {end }} / d_{0}=1.09$ $(\mathrm{P}=0,004)$.

We estimate that B16-F1 cells reached their maximal size $5 \mathrm{~min}$ after exposure to hypotonic buffer, while V79 and CHO cells reached their maximal size at approximately $2 \mathrm{~min}$. The size increase was the smallest for B16-F1 cells $\left(\mathrm{d}_{\max } / \mathrm{d}_{0}=1.18\right)$ and larger for V79 and CHO cells $\left(\mathrm{d}_{\max } / \mathrm{d}_{0}=1.26\right.$ and 1.29 respectively). However, described differences among cell lines were not statistically significant. Cells in the isotonic buffer did not change their size (data not shown).

After the initial swelling all cell lines underwent regulatory volume decrease and cells shrank gradually to diameters near original ones, despite the persisting hypotonic treatment, but with some differences between cell lines. During our observation, V79 and CHO cells shrank to their original size, while B16-F1 cells remained significantly enlarged $\mathrm{d}_{\text {end }} / \mathrm{d}_{0}=1.09(\mathrm{P}=0,004)$. Consequently, a regulatory volume decrease was faster with $\mathrm{CHO}$ and V79 cells and slower with B16-F1 cells.
A completely different behaviour was found in NS1 cell line under the same hypotonic treatment. The hypotonic treatment led NS1 cells to blebbing and expressing non-spherical shapes (Figure 3). Therefore, no cell swelling and consequent regulatory volume decrease was observed or measured for this cell line.

\section{Cell size response to electroporation in isotonic and hypotonic buffer}

We monitored cell size (diameter) changes in B16-F1 cells after the electroporation. Cells were exposed to the hypotonic buffer for $1 \mathrm{~min}$ before delivery of the pulses. In this study we used electrical pulse parameters that are optimal for the reversible electroporation of cells in the isotonic buffer as described in Materials and methods.

From the microphotographs the diameter of an individual cell was measured and normalized to the original diameter in the 


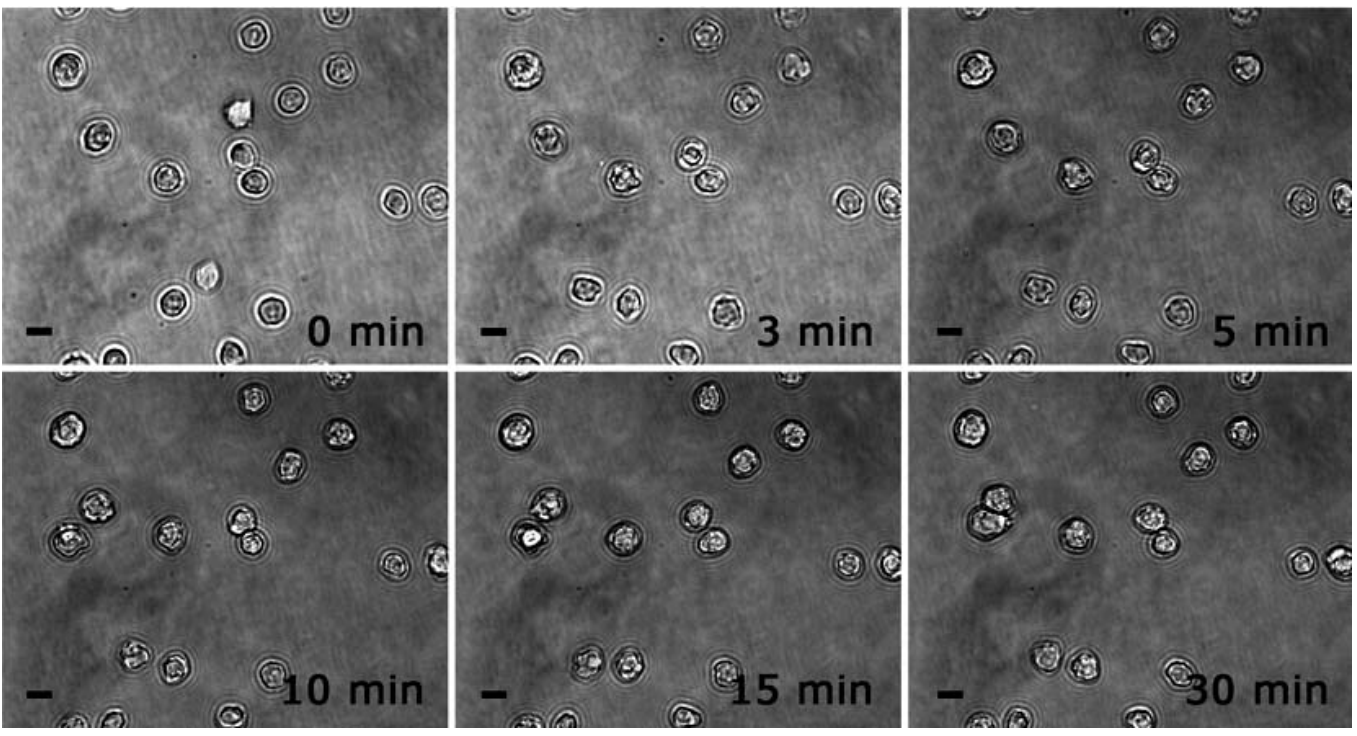

Figure 3. Mouse myeloma cells NS1 in 100 mOsm buffer containing sucrose as the major osmolyte. The image shows the behaviour of the cells during the hypotonic treatment. These cells did not exhibit any regular size alterations. Instead, NS1 cells started to bleb and express non-spherical shapes. Scale bar corresponds to $10 \mu \mathrm{m}$.

isotonic buffer $\left(v=\mathrm{d} / \mathrm{d}_{0}\right.$, Figure 4$)$. Within 1 min after the buffer change from isotonic to hypotonic, cells started to swell as in previous experiments without electroporation. We observed that the electroporation inhibited the effect of regulatory volume decrease completely during the $30 \mathrm{~min}$ of our observation. Cell swelling dynamics was also observed in B16-F1 cells electroporated in the isotonic buffer where a lower magnitude of swelling was measured (Figure 4).

\section{Cell viability after hypotonic treatment}

The cell viability of fusion partners needs to be preserved in order to produce viable hybrid cells. We, thus, analyzed the cell viability for all cell lines with a crystal violet (CV) viability assay. Results of the viability assay for hypotonically treated cells are shown in Figure 5. We observed no decrease in viability indicating that most of the cells survive the hypotonic treatment.

In the second part of our study, where we studied the effect of electroporation on
B16-F1 cells swelling in hypotonic buffer, cell the viability was also analyzed (Figure 6). The viability of electroporated cells significantly decreased in the hypotonic buffer to $63 \%(\mathrm{P}=0.002)$ while in the isotonic buffer the viability was not affected $(\mathrm{P}>0.1)$.

\section{Discussion}

Electrofusion in the hypotonic buffer is a promising approach for improving the cell fusion efficiency. Improved electrofusion conditions can be achieved with the hypotonic treatment. However, the duration and the strength (the osmolarity) of the hypotonic treatment should be optimized for the specific cell type. In the first part of our study, we determined cell size dynamics and survival of different cell lines in the hypotonic buffer. In the second part, we determined the influence of the electroporation on B16-F1 cell size dynamics and the survival in hypotonic buffers. 


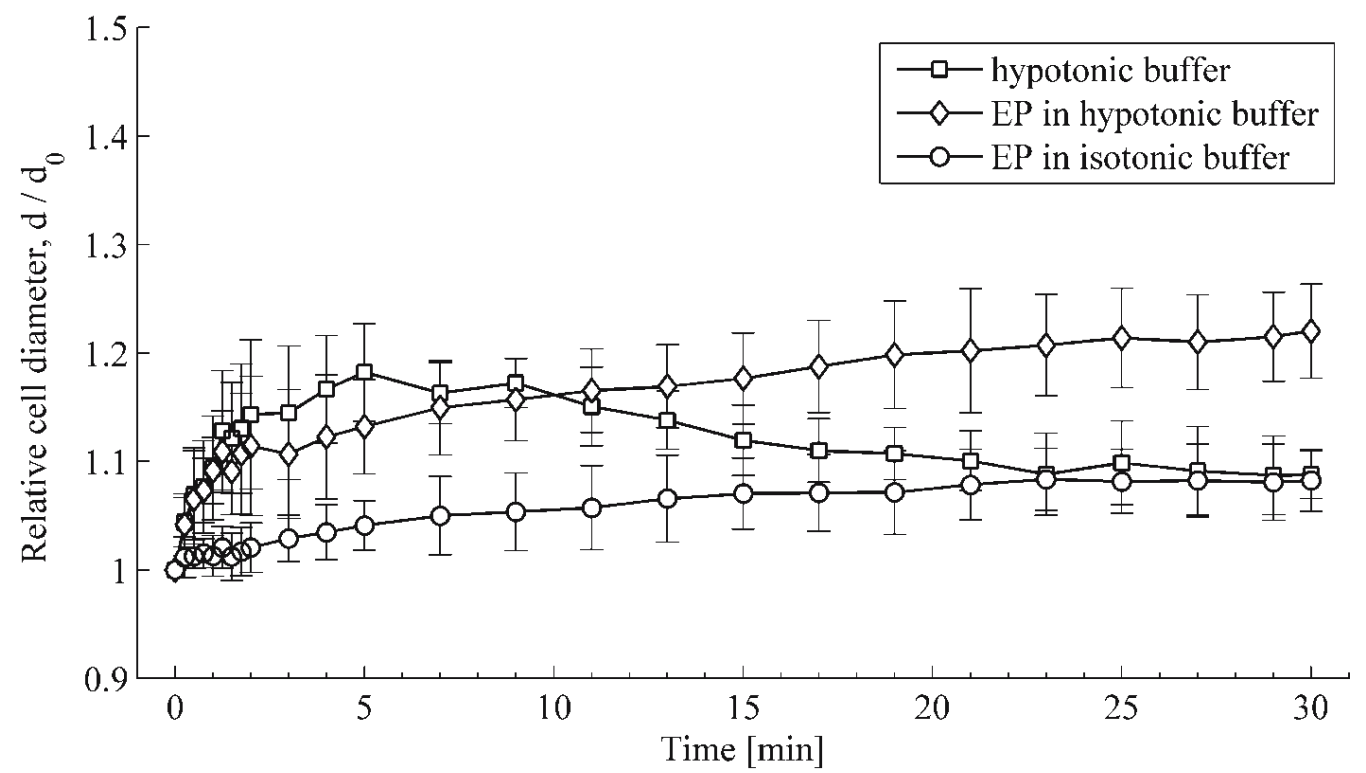

Figure 4. Time courses of relative cell diameter $\left(\mathrm{d} / \mathrm{d}_{0}\right)$ during the hypotonic treatment for B16-F1 cells. Squares $(\square)$ represent cells in the hypotonic buffer. Rhombs $(\diamond)$ represent cells in the hypotonic buffer, which were electroporated at $t=1 \mathrm{~min}$. Circles $(\mathrm{O})$ represent cells in the isotonic buffer, electroporated at the same time $(\mathrm{t}=1$ $\mathrm{min})$. Cell diameter was obtained by directly measuring the size of the cells. Each data point represents the mean \pm STD of at least three repetitions.

Electroporation was performed before a regulatory volume decrease took place.

In cell size dynamics we observe similar behaviour for cell lines B16-F1, V79 and $\mathrm{CHO}$. In those cells as in many other mammalian cells the initial hypotonic swelling was accomplished within 2-5 min (Figure 2). ${ }^{34,38-41}$ The maximal cell size increase was between 1.18 and 1.29 (Figure 2), the values that can be also found in the previously published studies. ${ }^{33-35,38,40-42}$ The only exception was cell line NS1 that will be described later on. Observed cell swelling is a desired phenomenon in electrofusion. The increase in cell size requires the unfolding of undulations and invaginations of cell membrane. ${ }^{42,43}$ This decrease in membrane undulations results in the decrease of undulation repulsive forces, yielding better cell-cell contacts. ${ }^{31,44-47}$

Differences among cell lines were found in regulatory volume decrease dynamics.
The expression of a regulatory volume decrease depends on the type of sugar that is used as osmolyte. Cells can express a regulatory volume decrease in buffers containing disaccharide as major osmolyte whereas when monosaccharide is used, the regulatory volume decrease is inhibited. The different effect of sugars was explained by volume-sensitive channels in the plasma membrane that are selectively transporting monomeric sugars but are poorly permeable for oligosaccharides. ${ }^{34,35,40}$ In our study such behaviour was observed for V79 and $\mathrm{CHO}$ cells that showed the fast regulatory volume decrease, mainly completed within 10-20 min (Figure 2).

In contrast to V79 and $\mathrm{CHO}$, only a partial regulatory volume decrease was observed for B16-F1 cells $\left(\mathrm{d}_{\text {end }} / \mathrm{d}_{0}=1.09\right.$, Figure 2 ). Similar phenomena was reported for the Jurkat leukemic cell line $\left(\mathrm{d}_{\text {end }} / \mathrm{d}_{0}=1.11\right)$ and murine fibroblast $\left(\mathrm{d}_{\mathrm{end}} / \mathrm{d}_{0}=1.12\right) \cdot{ }^{33,40} \mathrm{~A}$ 


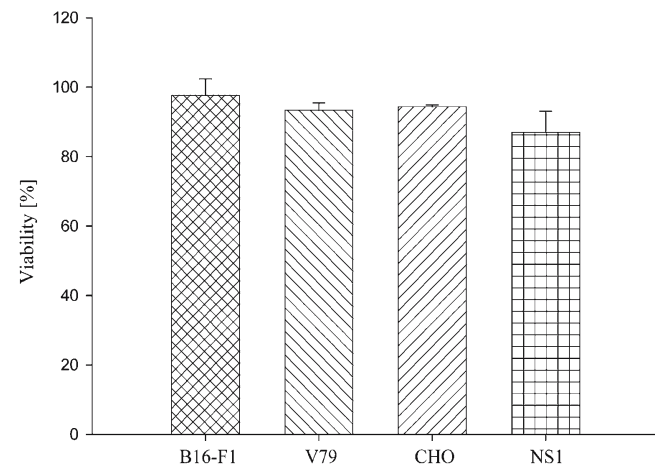

Figure 5. Viability of four different cell lines exposed to the hypotonic treatment (100 mOsm buffer containing sucrose as major osmolyte) for 30 minutes. Data represent mean \pm STD of at least three independent experiments.

partial regulatory volume decrease in epithelial and cancerous cell lines was attributed to the fact that those lines may slowly uptake sucrose. This uptake of oligosaccharides ${ }^{48,49}$ can explain the partial inhibition of regulatory volume decrease observed in B16-F1.

According to published literature the same hypotonic treatment causes different response in different cell lines due to their different (hypotonic) sensitivity. ${ }^{33,40,41,43}$ In mouse myeloma cells NS1 no swelling and regulatory volume decrease were observed. Instead, NS1 cells started to bleb and express non-spherical shapes (Figure 3). A similar behaviour was reported earlier for different cell lines when too hypotonic treatment (30 to $60 \mathrm{mOsm}$ ) was used. ${ }^{41,43}$ Therefore, we conclude that NS1 cells are more sensitive to a hypotonic treatment than other cell lines used in our study. Higher buffer osmolarities may have to be used for NS1 cells in order to obtain spherical cell shape with smooth membrane favourable for the electrofusion.

Regardless to immediately observed effect of the hypotonic treatment on cell size and shape, the cell viability was not affected (Figure 5). Those results show that the duration of hypotonic treatment and buffer

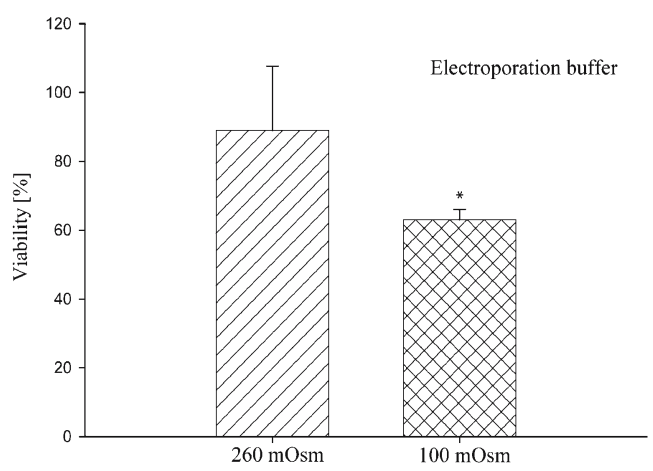

Figure 6. Effect of electroporation in both, hypotonic and isotonic buffer on viability of B16-F1 cells. Eight pulses of $100 \mu$ s duration at $1000 \mathrm{~V} / \mathrm{cm}$ electric field intensity at $1 \mathrm{~Hz}$ pulse repetition frequency were applied to the cells in $100 \mathrm{mOsm}$ and $260 \mathrm{mOsm}$ buffer containing sucrose as major osmolyte. Data represent mean \pm STD of at least three independent experiments. The Paired Sample T test showed that the viability of electroporated cells significantly decreased in the hypotonic buffer $(\mathrm{P}=0.002)$ while in the isotonic buffer the viability was not affected $(\mathrm{P}>0.1)$.

hypoosmolarity were properly selected and are in agreement with literature. ${ }^{40,50,51}$ Interestingly no significant decrease in cell viability was observed for NS1 cells, even though the hypotonic treatment caused cell blebbing.

In the second part of our study we determined the influence of the electroporation on B16-F1 cell size dynamics and the survival in the hypotonic buffer. Electroporation by itself causes swelling of electroporated cells in the isotonic buffer ${ }^{36}$, which was also observed in our experiment with B16-F1 cells (Figure 4). Electroporation induced cell swelling was significantly amplified if the hypotonic buffer was used and, therefore, regulatory volume decrease was inhibited (Figure 4).

However, electroporation in the hypotonic buffer was associated with a significant loss of cell viability (Figure 6) that was also observed in the study of Golzio et al. ${ }^{47}$ Electric field parameters for electroporation in the hypotonic buffer should be carefully selected in order to preserve cell viability since hypotonic treatment causes a higher 
susceptibility due to the increase in cell size. ${ }^{16,28,30-33,39,52}$

In conclusion, cell size dynamics should be carefully analyzed and observed for each cell line in order to obtain all potential benefits of using hypotonic buffer for electrofusion. Electroporation should be performed when cells are close to their maximal size i.e. before the regulatory volume decrease starts. In addition, electroporation parameters should be adjusted to hypotonically induced changes on cells in order to preserve the cell viability.

\section{Acknowledgements}

We thank Prof. Vladka Čurin Šerbec from Blood Transfusion Centre of Slovenia for providing us with NS1 cells. This research was supported by the Slovenian Research Agency (ARRS). The authors would also like to thank Dr. Tomaž Jarm for his help with statistics and to Duša Hodžić for manuscript reading and her useful comments.

\section{References}

1. Chang DC, Chassy BM, Saunders JA, Sowers AE. Guide to Electroporation and Electrofusion. San Diego: Academic Press; 1992.

2. Hui SW, Stenger DA. Electrofusion of cells: Hybridoma production by electrofusion and polyethylene glycol. Method Enzymol 1993; 220: 212-27.

3. Zimmermann U, Friedrich U, Mussauer H, Gessner P, Hämel K, Sukhorukov V. Electromanipulation of mammalian cells: Fundamentals and application. IEEE IEEE Trans Plasma Sci 2000; 28: 72-82.

4. Zimmermann U. Electric field-mediated fusion and related electrical phenomena. Biochim Biophys Acta 1982; 694: 227-77.

5. Teissie J, Rols MP. Fusion of mammalian cells in culture is obtained by creating the contact between cells after their electropermeabilization. Biochem Biophys Res Commun 1986; 140: 258-66.
6. Neumann E, Kakorin S. Digression on membrane electroporation and electroporative delivery of drugs and genes. Radiol Oncol 1998; 32: 7-17.

7. Rudolf Z, Stabuc R, Cemazar M, Miklavcic D, Vodovnik L, Sersa G. Electrochemotherapy with bleomycin. The first clinical experience in malignant melanoma patients. Radiol Oncol 1995; 29: 229-35.

8. Cemazar M, Miklavcic D, Vodovnik L, Jarm T, Rudolf Z, Stabuc R, et al. Improved therapeutic effect of electrochemotherapy with cisplatin by intratumoral drug administration and changing of electrode orientation for electropermeabilization on EAT tumor model in mice. Radiol Oncol 1995; 29: 121-7.

9. Sersa G, Cemazar M, Miklavcic D. Tumor blood flow modifying effects of electrochemotherapy: a potential vascular targeted mechanism. Radiol Oncol 2003; 37: 43-8.

10. Sersa G, Cemazar M, Miklavcic D, Rudolf Z. Electrochemotherapy of tumours. Radiol Oncol 2006; 40: 163-74.

11. Pavselj N, Miklavcic D. Numerical modeling in electroporation-based biomedical applications. Radiol Oncol 2008; 42: 159-68.

12. Zupanic A, Corovic S, Miklavcic D. Optimization of electrode position and electric pulse amplitude in electrochemotherapy. Radiol Oncol 2008; 42: 93-101.

13. Tsong TY. Electroporation of cell membranes. Biophys J 1991; 60: 297-306.

14. Teissié J, Rols M. An experimental evaluation of the critical potential difference inducing cell membrane electropermeabilization. Biophys J 1993; 65: 409-413.

15. Weaver JC, Chizmadzhev YA. Theory of electroporation: A review. Bioelectrochem Bioener 1996; 41: 135-60.

16. Neumann E, Sowers AE, Jordan CA. Electroporation and electrofusion in cell biology. New York: Plenum Press; 1989.

17. Cemazar M, Jarm T, Miklavcic D, Macek-Lebar A, Ihan A, Kopitar NA, et al. Effect of electric-field intensity on electropermeabilization and electrosensitivity of various tumor-cell lines in vitro. Electro Magnetobiol 1998; 17: 263-72.

18. Canatella PJ, Karr JF, Petros JA, Prausnitz MR. Quantitative study of electroporation-mediated molecular uptake and cell viability. Biophys $J$ 2001; 80: 755-64. 
19. Macek-Lebar A, Miklavcic D. Cell electropermeabilization to small molecules in vitro: control by pulse parameters. Radiol Oncol 2001; 35: 193-202.

20. Cegovnik U, Novakovic S. Setting optimal parameters for in vitro electrotransfection of B16F1, SA1, LPB, SCK, L929 and CHO cells using predefined exponentially decaying electric pulses. Bioelectrochemistry 2004; 62: 73-82.

21. Kanduser M, Sentjurc M, Miklavcic D. Cell membrane fluidity related to electroporation and resealing. Eur Biophys J 2006; 35: 196-204.

22. Vienken J, Zimmermann U. An improved electrofusion technique for production of mouse hybridoma cells. FEBS Lett 1985; 182: 278-80.

23. Mally MI, McKnight ME, Glassy MC. Protocols of electroporation and electrofusion for producing human hybridomas. In: Chang D, Chassy B, Saunders J, Sowers A, editors. Guide to Electroporation and Electrofusion. San Diego: Academic Press; 1992. p. 507-22.

24. Scott-Taylor TH,Pettengell R, Clarke I, Stuhler G, La Barthe MC, Walden $P$, et al. Human tumour and dendritic cell hybrids generated by electrofusion: potential for cancer vaccines. Biochim Biophys Acta 2000; 1500: 265-79.

25. Hayashi T, Tanaka H, Tanaka J, Wang R, Averbook BJ, Cohen PA, et al. Immunogenicity and therapeutic efficacy of dendritic-tumor hybrid cells generated by electrofusion. Clin Immunol 2002; 104: 4-20.

26. Yu X, McGrawa PA, House FS, Crowe JE Jr. An optimized electrofusion-based protocol for generating virus-specific human monoclonal antibodies. J Immunol Methods 2008; 336: 142-51.

27. Ahkong QF, Lucy JA. Osmotic forces in artificially induced cell fusion. Biochim Biophys Acta 1986; 858: 206-16.

28. Schmitt JJ, Zimmermann U. Enhanced hybridoma production by electrofusion in strongly hypo-osmolar solutions. Biochim Biophys Acta 1989; 983: 42-50.

29. Zimmermann U, Gessner P, Schnettler R, Perkins S, Foung SK. Efficient hybridization of mouse-human cell lines by means of hypoosmolar electrofusion. J Immunol Methods 1990; 134: $43-50$.

30. Foung S, Perkins S, Kafadar K, Gessner P, Zimmermann U. Development of microfusion techniques to generate human hybridomas. J Immunol Methods 1990; 134: 35-42.
31. Rols MP, Teissié J. Modulation of electrically induced permeabilization and fusion of Chinese hamster ovary cells by osmotic pressure. Biochemistry 1990; 29: 4561-7.

32. Rehman SMM, Perkins S, Zimmermann U, Foung SKH. Human hybridoma formation by hypo-osmolar electrofusion. In: Chang D, Chassy B, Saunders J, Sowers A, editors. Guide to Electroporation and Electrofusion. Academic Press; 1992. p. 523-33.

33. Sukhorukov VL, Reuss R, Zimmermann D, Held C, Müller KJ, Kiesel M, et al. Surviving highintensity field pulses: Strategies for improving robustness and performance of electrotransfection and electrofusion. J Membr Biol 2005; 206: 187-201.

34. Sukhorukov VL, Reuss R, Endter JM, Fehrmann S, Katsen-Globa A, Geßner P, et al. A biophysical approach to the optimisation of dendritictumour cell electrofusion. Biochem Biophys Res Commun 2006; 346: 829-39.

35. Kiesel M, Reuss R, Zimmermann D, Zimmermann H, Shirakashi R, Bamberg E, et al. Biophys J 2006; 90: 4720-9.

36. Pavlin M, Kanduser M, Rebersek M, Pucihar G, Hart FX, Magjarevic R, et al. Effect of cell electroporation on the conductivity of a cell suspension. Biophys J 2005; 88: 4378-439.

37. Gillies RJ, Didier N, Denton M. Determination of cell number in monolayer cultures. Anal Biochem 1986; 159: 109-13.

38. Sarkadi B, Attisano L, Grinstein S, Buchwald M, Rothstein A. Volume regulation of Chinese hamster ovary cells in anisoosmotic buffer. Biochim Biophys Acta 1984; 774: 159-68.

39. Barrau C, Teissié J, Gabriel B. Osmotically induced membrane tension facilitates the triggering of living cell electropermeabilization. Bioelectrochemistry 2004; 63: 327-32.

40. Reuss R, Ludwig J, Shirakashi R, Ehrhart F, Zimmermann $\mathrm{H}$, Schneider S, et al. Intracellular delivery of carbohydrates into mammalian cells through swelling-activated pathways. J Membr Biol 2004; 200: 67-81.

41. Zimmermann D, Terpitz U, Zhou A, Reuss R, Müller K, Sukhorukov VL, et al. Biophysical characterisation of electrofused giant HEK293cells as a novel electrophysiological expression system. Biochem Biophys Res Commun 2006; 348: 673-81. 
42. Knutton S, Jackson D, Graham JM, Micklem KJ, Pasternak CA. Microvilli and cell swelling. Nature 1976; 262: 52-4.

43. Sukhorukov VL, Arnold WM, Zimmermann U. Hypotonically induced changes in the plasma membrane of cultured mammalian cells. JMembr Biol 1993; 132: 27-40.

44. Evans EA, Parsegian VA. Thermal-mechanical fluctuations enhance repulsion between bimolecular layers. Proc Natl Acad Sci USA 1986; 83: 7132-6.

45. McIntosh TJ, Advani S, Burton RE, Zhelev DV, Needham D, Simon SA. Experimental test for protrusion and undulation pressures in phospholipid bilayers. Biochemistry 1995; 34: 8520-32.

46. McIntosh TJ, Kulkarni KG, Simon SA. Membrane fusion promoters and inhibitors have contrasting effects on lipid bilayer structure and undulations. Biophys J 1999; 76: 2090-8.

47. Golzio M, Mora MP, Raynaud C, Delteil C, Teissié J, Rols MP. Control by osmotic pressure of voltage-induced permeabilization and gene transfer in mammalian cells. Biophys J 1998; 74: 3015-22.

48. Siebens AW, Spring KR. A novel sorbitol transport mechanism in cultured renal papillary epithelial cells. Am J Physiol Cell Physiol 1989; 257(6 Pt 2): F937-46.

49. Hall JA, Kirk J, Potts JR, Rae C Kirk K. Anion channel blockers inhibit swelling-activated anion, cation, and nonelectrolyte transport in HeLa cells. Am J Physiol Cell Physiol 1996; 271: 579-88.

50. Neil GA, Zimmermann U. Electrofusion. Methods Enzymol 1993; 220: 174.

51. Zimmermann U, Neil GA. Electromanipulation of Cells. Boca Raton: CRC Press; 1995.

52. Kotnik T, Bobanovic F, Miklavcic D. Sensitivity of transmembrane voltage induced by applied electric fields - a theoretical analysis. Bioelectrochem Bioener 1997; 43: 285-91. 